\section{Håndbok ved livets slutt}

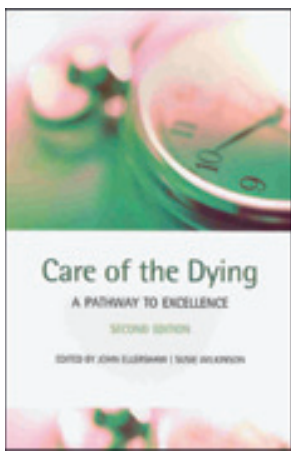

John Ellershaw, Susie Wilkinson, red. Care of the dying

A pathway to excellence. 2. utg. 260 s, tab, ill. Oxford: Oxford University Press, 2010.

Pris GBP 28

ISBN 978-0-19-955083-8

Helsetjenestene ved livets begynnelse er de siste årene blitt gjenstand for en rekke ulike kvalitetsforbedringstiltak, med akkreditering og sertifisering av avdelinger. Ved Marie Curie Palliative Care Institute ved University of Liverpool har man de siste 13-14 årene brukt samme type metodikk for livets andre ytterpunkt. Et kontinuerlig kvalitetsforbedringsarbeid har resultert i en rekke påfølgende versjoner av Liverpool Care Pathway for Care of the Dying, en tiltaksplan for omsorg til døende og deres pårørende. Versjon 12 av tiltaksplanen ble lansert i november 2009, og den foreliggende boken er først og fremst ment som en veileder for brukerne av denne planen. Samtidig har forfatterne klart å lage en lettlest og brukervennlig håndbok for alle som gir behandling og pleie til døende pasienter.

Innholdet faller naturlig i tre deler. Den begynner med en omtale av «care pathways» som verktøy, og en grundig gjennomgang av Liverpool Care Pathway (LCP). Så følger flere kapitler som gir utfyllende informasjon i forhold til temaer som inngår i planen: symptomlindring, etiske utfordringer, kommunikasjon, åndelige og eksistensielle utfordringer, ivaretaking av pårørende og av barn spesielt. Siste del omhandler implementering og spredning av tiltaksplanen: strategiske råd for innføring av verktøyet på den enkelte arbeidsplass, opplegg for revisjon/bruksevaluering i liten og stor skala samt et eget kapittel om internasjonale erfaringer. I appendikset er LCP-versjon 12 inkludert i sin helhet, sammen med eksempler på utfylling av planens enkelte deler, behandlingsalgoritmer for de vanligste symptomene hos døende og informasjonsskriv til pårørende.

Den medisinsk- og sykepleiefaglige midtre delen er skrevet av anerkjente fagpersoner i det palliative feltet. Dette er kortfattede, poengterte kapitler, for en stor del bygd opp rundt spørsmål og svar, med oversiktlige tekstbokser og tabeller. Noen kapitler er rene perler, slik som Susie Wilkinsons om kommunikasjon, og Barbara Monroes om ivaretaking av barn rundt et dødsfall. Kapitlet om etikk kan virke så summarisk at det står i fare for å bli overfladisk, men det spørs om det ikke innholder akkurat den kortfattede, klare informasjonen som travle klinikere trenger. Alle kapitler er utstyrt med referanselister, og mange har forslag til videre lesning og nyttige nettsteder.

LCP har i løpet av få år fått internasjonal anerkjennelse som det ledende kvalitetsverktøyet for terminal pleie. Planen brukes nå i mer enn 20 land og er tema for et stort EU-prosjekt. I løpet av de siste par årene er LCP tatt i bruk en rekke steder i Norge. Denne boken er en obligatorisk håndbok for alle brukersteder. Jeg anbefaler den ellers for alle som tar hånd om døende pasienter. Innholdet er akkurat så praktisk, hverdagsnært og gjennomarbeidet at tittelen kan forsvares.

\section{Dagny Faksvåg Haugen}

Kompetansesenter i lindrende behandling

Helseregion Vest

\section{Å være to skritt foran...}

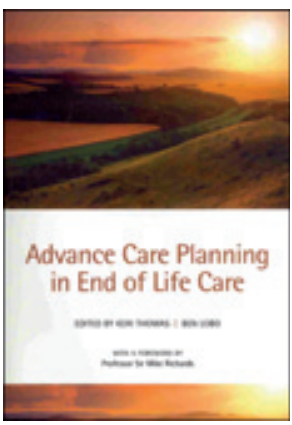

Keri Thomas, Ben Lobo, red.

Advance care planning in end of life care

305 s, tab, ill. Oxford: Oxford University Press, 2010. Pris GBP 30

ISBN 978-0-19-956163-6

Denne systematiske og oversiktlige læreboken beskriver hvordan man på ulike måter kan være «to skritt foran» i planlegging av behandling, omsorg og pleie når døden nærmer seg. Hovedbudskapet er god kommunikasjon, og ved å starte en åpen og ærlig dialog tidlig nok, øker mulighetene for å tilrettelegge etter pasientens ønsker.

Boken er lettlest og fri for kompliserte faguttrykk, og målgruppen er ikke bare leger som arbeider innenfor relevante fagområder som palliativ medisin og sykehjemsmedisin. Her vil alle som arbeider med mennesker i siste livsfase, det være seg ulike helsearbeidere og ledere, samt pårørende ha stor nytte av å sette seg inn i tankegangen som preger denne boken.

Forfatterne tar for seg ulike aspekter av «advance care planning (ACP)», og det er 24 selvstendige kapitler samlet i fem seksjoner, der over 40 bidragsytere fra store deler av verden med betydelig klinisk og akademisk kompetanse belyser ulike temaer. Blant annet blir hjerte-lunge-redning og annen livsforlengende behandling behørig diskutert.

Boken starter med en oppsummering av foreliggende kunnskapsgrunnlag, tar oss så gjennom implementeringen av «advance care planning» i Englands strategi for omsorg i livets sluttfase og bringer deretter inn erfaringer fra USA, Canada og Australia. I de to siste kapitlene beskrives strukturering av arbeidet i forhold til den enkelte pasient, og hvordan «advance care planning» kan implementeres som en naturlig del av de lokale helsetjenester.

Ved hjelp av faktabokser, nøkkelpunkter og rikholdige pasienteksempler gir forfatterne synspunkter og råd og underbygger dem med sentrale referanser.

Hvert kapittel har et selvstendig budskap som kan leses og brukes separat, med konkrete praktiske råd og ideer til prosedyrer og retningslinjer. Samtidig går det en rød tråd gjennom hele boken som binder kapitlene naturlig sammen.

Det poengteres sterkt at planlegging av behandling i livets sluttfase handler om god kommunikasjon over tid, gjennom flere repeterte møtepunkter der det bygges tillit mellom helsearbeideren og den syke. På denne måten vil god fagkunnskap på en respektfull måte tilpasses den sykes ønsker og forventninger i den siste livsfasen.

En systematisk tilnærming til de ulike utfordringer pasienten møter når livet nærmer seg slutten, er ikke godt nok integrert $i$ det norske helsevesen, som altfor ofte preges av ad hoc-løsninger med ganske uforutsigbart utfall.

Eksemplene er mange: akutte innleggelser av døende sykehjemspasienter, utrykning med ambulanse til døende hjemmeboende pasienter, legevakthenvendelser som ender i unødvendige og uverdige innleggelser. Kanskje det også forklarer at Norge ligger på bunn i Europa når det gjelder hjemmedødsfall.

I det nordiske spesialistkurset i palliativ medisin er «advance care planning» med som et hovedtema. Forhåpentligvis bærer dette frukter etter hvert som flere leger tar denne utdanningen. Denne boken er et vesentlig bidrag til å få til en bedre planlegging når livet går mot slutten, og bør være tilgjengelig på alle kliniske avdelinger og sykehjemsavdelinger, ikke bare på spesialiserte palliative enheter. $\AA$ bla i denne boken kan gi store forbedringer gjennom konkrete råd for kommunikasjonen med den syke, men også ved 